\title{
STRUCTURAL AND WORD-FORMATIVE FEATURES OF VERBS OF BEHAVIOR IN THE TATAR LANGUAGE
}

\author{
Firuza R. Sibgaeva ${ }^{1}$ \\ Ruzilya R. Salakhova ${ }^{2}$ \\ Mahira N. Huseynova ${ }^{3}$
}

\begin{abstract}
The articles are devoted to the study of one of the lexico-semantic groups of verbs in the Tatar language behavioral verbs, which mean the action and actions of a person who has received one or another social coloring: This group of verbs differs from the verbs of other lexico-semantic groups by specific features: they represent the principles of human behavior in society. The relevance of the topic lies in the fact that the Tatar language does not study the structural-word-and-phraseological features of the verbs of behavior that would contribute to a complete and comprehensive analysis of the lexical structure of the grammar. In the article, the derivational possibilities of the Tatar language verbs at the level of the wordderivative paradigm are determined. In
\end{abstract}

particular, the structural specificity of this verbal vocabulary was revealed, word-derivative values of suffixes forming behavioral verbs were revealed, as well as a number of auxiliary and modifying participles were also demonstrated. The analysis of structural and word-formative possibilities of verbs of behavior allows to reveal the specificity of relations between derivational and semantic segments of verbs of this group, and will also serve as a material for the study of the semantic relationship between motivating and motivated words.

Keywords: Tatar language; semantics; a verb; verbs of behavior; word formation.

\section{Vvedenie Introduction}

\footnotetext{
${ }^{1}$ Kazan Federal University.

$\mathbf{W}$

TATAR LANGUAGE

${ }^{2}$ Kazan Federal University. Email: TENDENCIES OF COI ruzilya5@ mail.ru.

${ }^{3}$ Azerbaijan state pedagogical University.
} 
Verbs in the Tatar language are the most interesting and the most difficult part of speech. Many of its categories have been studied deeply enough, but some questions of a grammatical character remain unexplored. These include the issues of verbal spelling of lexico-semantic groups of verbs in general and the spelling of verbs in general.

As linguists point out, lexicosemantic groups combine words according to the proximity of lexical values [M.M. Keruly, et. al, 2018]. A lot of lexico-semantic groups is a measure of the wealth of the semantic system of language vocabulary. Vibrants of the Tatar language, where the thematic groups are widely represented, are a striking example. Based on the general semantic content of the verbs, F.A. Ganiev divides them into 11 categories, which have the following subgroups: movement verbs, action verbs, process verbs, state verbs, behavioral verbs, playing verbs, playing verbs, playing them.

As was noted above, the object of study in our researching are Tatar language verbs of behavior. This group of verbs was reflected in the monograph of R.K. Ishtanova [R.K. Ishtanova, 2002], where the lexico-semantic groups of Tatar language verbs are examined in detail.

Of particular interest is the monograph by A.M. Aydarova, where structural and semantic features of the verbs of behavior are studied in Russian, Tatar and English [A.M. Aydarova, 2016].

The object of this study is the derivative verbs of the Tatar language that arose as a result of the wordformation process.

The purpose of this article is to study the semantic and structurally verbal-expressive features of the verbs of behavior in the Tatar language.

\section{Materials and Methods}

The main material for scientific analysis is extracted from universal dictionaries and reference books, a lexical corpus is composed in the amount of 147 units. Examples are drawn from the works of the classic of Tatar literature, one of the most respected authors of the twentieth century of Amirkhan Enika. Based on a wealth of factual material, an exhaustive analysis of the verbs of behavior is carried out, 
and their structural and word-formation features are described.

The theoretical and methodological basis of the research was the scientific works of turkologists and Tatar linguists on lexicology and word formation, as well as explanatory dictionaries of the Tatar language.

The study used the following methods: semantic and structural, as well as word-formation analysis of lexical units, statistical method.

\section{Results and discussion}

Having examined the structure of behavioral verbs in the Tatar language, synthetic (non-derivative, suffixive) and analytic verbs (complex, compound, paired) were identified. To synthetic verbs after F.A. Ganievym [F.A. Ganiev et. al, 2005] we carry non-derivative verbs ( qabaru 'to pyzhitsya', qarishu 'to be obstinate', jarau 'to ugozhdat' and so forth) and suffixal ( irencheklenu 'to lenitsya', qiyulanu 'to khrabritsya', shaulashu 'to shumet' and so on). The latter are common among the verbs of behavior.

The suffix -lan/-len in the modern Tatar language is one of the most productive and multi-valued. Many
Turkologists attribute it to the return security suffix. Some linguists do not distinguish it as a special suffix. After the appearance of the works of E.V. Sevortyan on the verbal word-formation, he began to consider it as an independent word-forming affix. It consists of two elements - - $\boldsymbol{l a}$ and $\boldsymbol{- n}$ and will join such parts of the speech, as nouns, adjectives, numerals.

This suffix in the formation of behavioral verbs has the following meanings:

1) "to perform an action that is characteristic of a person or an animal expressed as a producing base" [Tatar grammar, 1993]: majmillanu 'to monkey', kejelenu to 'lock up'. Hezer nishliseņ inde, barmyjm dip keжçelene bashlasah, abzykaj je tuzyp kiter, апyн talkany hervakytta kory bula [A. Eniki, 2002]. But now you'll have to go, you'll lock up - you'll only drive the uncle away, but he doesn't like to go to church [A. Enikeev, 1988].

2) "acquire the characteristic of a person or animal or become what is designated as the producing basis" [Tatar grammar, 1993] ushenlenu / jaukaulanu 'become / become lazy'; Mine de vakytvakyt joky basyp kitkelede, lekin kulda 
dilbege bulgach, bireshmedem, kundugaipun kuelle gene chynlavyn, yulendagy chikertkelernen yalkaulanyp chyryldaganyn tynlap, uz ujlaryma jotylyp bara birdem [A.Eniki. 2002]. I, too, was falling asleep, but I fastened and, listening to the ringing of the bell, to the unhurried sound of the blacksmiths, thought of myself [A. Enikeev, 1988].

3) "to show the property, quality or characteristic designated by the producing basis" [Tatar grammar, 1993] ersezlenu 'to show shamelessness, to be impudent', edepsezlenu 'to behave indecently, rudely', unaysizlanu 'to be shy, embarrassed'. Shulaj kyzaryp, uң̧ajsyzlanyp kyna min, koda babaj, kodagyj ebi, Hobejdulla koda belen kureshtem, emma kodachalarga kul suzarga kochem жçitmede [A. Eniki, 2002]. I myself, too, and from this shyness, was even more so, I halfquarreled with the old people, with my brother-in-law Khobaybulla, but giving my young sister-in-law's hands was beyond my power [A. Enikeev, 1988].

4) "acquire that quality, property or attribute that is expressed by the producing basis" [Tatar grammar, 1993]: rekhimsezlenu 'become / become merciless'; qomarlanu 'become / become greedy', kirelenu, tiskerelenu 'become obstinate become / become stubborn'. Nishlim min anda? , - didem min tiskerelenep [A. Eniki, 2002]. - What I didn't see there? - I straightened up [A. Enikeev, 1988].

5) "to perform an action related to the content of the producing base" [Tatar grammar, 1993]: qarulanu 'to protest', kaprizlanu 'to act up', tavishlanu 'to make noise', havalanu to show up. Ul bashka deeply Uzеңе tue Kesha, Andy vakyt оstеңуе уаң̧а in de Kiem tekterep sorrows, ezrek klyң̧a akcha also one kyskazy, Bernice kon ditch Kinect usep kitchen, Khursheddash malajlarnym kuzlere yandirip the aeration biresem jori [A. Eniki, 2002]. Yes, needless to say, the wedding of a loved one - something quite different: then you dressed up to the nines, even give money, go so important, boys from the street, of course, $n$ you know, I do not notice a burning envy eyes [A. Enikeev, 1988].

As can be seen from the examples, some derivative verbs of behavior with the affix -lan have metaphorical meanings. For example, 
the verb hawalanu (hawa - 'the sky') 'arrogant'.

Thus, verbs, derivative verbs with a given word-forming affix, express the following meaning: "to be similar to someone or something expressed by a derivative basis, which is a kind of similarity to people.

Let us also consider another word-forming affix, which forms the verbs of behavior in the Tatar language, but is inferior to the previous one in productivity - the suffix -la / -le. It is an ancient Turkic word-forming suffix. In modern Tatar language, it is considered one of the most productive and multimeaning suffixes. In the formation of behavior verbs, the generating bases are mainly nouns. So, the noun -la model expresses the following meanings:

1) "to put someone or something the act or ritual that expressed the basis of" [Tatar grammar, 1993] jeberleu 'to offend', miscella 'insult', meshereleu 'mock', gazaplau 'to torment'; Mene shushy bilgesezlek mine borchyp, urtep, apomu gazaplap tora ide shikelle [A. Eniki, 2002]. And the very fact that I was worried constantly drove me away, imagined, tormented my soul [A. Enikeev, 1988; Zhampeisov,2018].
2) "to manifest that property, quality, or relationship that is called the producing basis" [Tatar grammar, 1993]: cadreral 'appreciate', khormetle 'adorn', taplau, qaralau 'stain, slander'; Sin yalgan suz sojlep, minem isememne taplagansyң, emma minem Merfugaga barmak belen de kagylganym bulmady [A. Eniki, 2002]. You fell upon me, stained my name, although I didn't touch Marfugu [A. Enikeev, 1988].

3) "to subvert someone to an action called the producing basis" [Tatar grammar, 1993]: jezala "punish", jeberle "oppress", tenqytle "criticize”, meskherele "insult". Kartlar kajda da ber iken: tenkyjt'legenne, жçeberlegenne yaratmyjlar [A. Eniki, 2002]. Old men, it turns out that they are the same everywhere, they don't like it, when they criticize them, they numb it [A. Enikeev, 1988].

The research material showed that in their structure, analytic verbs of behavior are divided into the following types:

1) actually complex (khiyenet itu 'change');

3) paired (borgalanu-sirgalanu 'flirt'); 


\section{Sireinere}

Periódico do Núcleo de Estudos e Pesquisas sobre Gênero e Direito

Centro de Ciências Jurídicas - Universidade Federal da Paraíba V. 8 - N 07 - Ano 2019 - Special Edition ISSN | 2179-7137 | http://periodicos.ufpb.br/ojs2/index.php/ged/index
4) composite (aptirap qalu 'grow up').

Actually-complex verbs are derived from the names of the essential words-forming auxiliary verbs itu, bulu, kylu, kilu, yasau, and also less productive biru,. The semantic and functional features of the above verbs have common features with the suffixive behavior verbs -la / -le . For example: khormetleu - khormet itu 'to be respected', meskhereleu - meskhere itu to 'humiliate'. As can be seen from the examples, the different-structured derivative verbs of behavior express the same meaning and are included in a single synonymous series, thereby enriching the lexical composition of the language.

One of the most productive among complex behavior verbs is wordforming constructions with an auxiliary verb itu, and the first component can be paired words, for example, such as: and loans: meskhere itu 'to disgrace; insult ', misqil itu' humiliate ', khur itu' humiliate ', khiyenet itu' mutilate '; and suffix derivative words such as usalliq itu 'to atrocity', shuqliq itu 'to play pranks.' Selime ire tapkan malny ж⿻̧一𠃋е eremsherem ituche hatyn tugel [A. Eniki,
2002; Mnunguli \& Kisangiri 2018]. Salima is not one of those who easily distributes the earnings earned by her husband [A. Enikeev, 1988].

At the second place in terms of productivity, constructions with the verb kylu, which in the works of L.M. Akhmetzyanova marked maloproductivnymi in modern Tatar language in connection with its transition to the archaic form [L.M. Akhmetzyanova et. al, 2018; Rezaei \& Nemati 2017]. Actually, in modern Tatar literary language there is a limited number of constructions with the verb kilu, however they have stylistic features. Consider them: gonah qilu 'sin', zalimlek qilu 'tyranny', zina qilu 'change', meshere qilu 'to disgrace; insult ', khiyenet qilu' change'. - Min ber gonah ta kylmadym, min bary tik Hobejbullany kisetmekche gene buldym, - dip aklandy Meftuha [A. Eniki, 2002]. "I am not to blame for anything, I just wanted to warn Khubaybulla," Maftuha denied

$$
\text { [A. }
$$

Enikeev, 1988;

Metsämuuronen, 2018].

Paired verbs are formed only according to one type - "verb + verb". Their values are often not reducible to the values of their components - it 
presents some generalization, sometimes even abstraction. This sign is how and once creates a paired verb. For example, bogelu-sigilu 'flirting'; yalinu-yalvaru 'plead'; oyalu-kizaru, oyalu-иң̧аjsyzlanи 'shy, embarrassed'. Lekin Bedretdin uze tynych ide, herhelde, oyalu-uщ̧ajsyzlanu kebek bernerse de sizdermi ide. However, we noticed that Badretdin himself was not at all embarrassed.

Paired verbs of behavior of this type of education in the language have several types. Sometimes it is very difficult to determine whether a given verb is a paired verb or is it just a complex verb form of the corresponding stem. Questions arise when determining paired adverbs, therefore, it is necessary to possess information about wordbuilding types and models of derivative words. For example, the word-formation type "verb + verb" and the model "participle in $\boldsymbol{- p}+$ participle in $\boldsymbol{- p}$ " form paired adverbs: yelap-syktap 'with tears', tyryshyp-tyrmashyp 'diligently'. These models cannot be considered as paired verb forms, because the language does not have paired verbs yelau-syktau, tyryshu-tyrmashu. As a rule, they are not used in finite forms: yelady-syktady, tyryshty-tyrmashty, since derived behavior verbs do not have such a derivational type.

Composite verbs - "these are words that consist of at least two components, which are relatively stable combinations and are in homonymous relations with free phrases" [K. Shermaymayti et. al, 2018]. These are complex constructions, the second element of which are word-forming desemantized verbs. The most productive (de-semantized) modifying verbs in the formation of compound verbs of behavior are beteru, joru, kitu, kalu, toru, toshu, yatu [G.N. Khusnullina et. al, 2017]. Thus, for example, the verb beteru means the following: "manifestation of the action to the fullest extent" (tinteretep beteru 'torment'). The word-forming verb kitu expresses the acquisition of any quality, property, or acquisition of any quality to a greater extent (usallanip kitu 'get angry', batilanip / gayretlenep kitu 'get unshaven'). The verb kalu means action, the whole subject is covered (aptirap qalu 'get embarrassed', kurqip qalu 'get scared'). Tutash aptyrap qaldy. The young lady was dispersed. The same meaning is also expressed by the toshu verb (aptiriy toshu 'spread out'). Eget 
beraz aptyryj toshte. The Guy a bit flustered.

\section{Summary}

In this way, in the wordformation plan, the productive way of forming the verbs of behavior is the suffix and phrase.

In the course of the study, the structural specificity of this verbal vocabulary was revealed, wordderivative values of suffixes that form behavioral verbs (suffixes -la/-le, -na/ne, lan/-len) and modifying (beteru, joru, kitu, kalu, toru, toshu, yatu) verbs that take an active part in the formation of the composite verbs of the group under study.

The semantics of most analytic verbs of behavior derived from nonverbs are regular (63\%); some may have an individual value (28\%); verbs of behavior also occur with a figurative meaning $(9 \%)$.

From the point of view of genesis, the first components in most cases are Tatar words (56\%). A certain layer of the first components of complex verbs of behavior is represented by Arabic-Persian borrowings (31\%). Borrowings from and through Russian can also be the first components of compound verbs of behavior (13\%).

Summing up, it should be noted that analytical (compound, complex, paired) verbs of behavior, as one of the specific lexical-semantic groups of the verb, should take their place in all types of dictionaries.

\section{Conclusion}

The results of this study, the factual materials and analyzes given, can be used in lexicographic activity, the development of special courses on the semantics and structure of the verb, in classes on the culture of speech. Actual material can become the basis of exercises for word formation, vocabulary and speech development in methodological manuals, textbooks for students of the Tatar language. It is not ruled out that the data obtained for the development of questions of identifying word-formation features of derived verbs and the creation of vocabulary dictionaries can be used.

\section{Acknowledgements}

The work is performed according to the Russian Government 
Program of Competitive Growth of Kazan Federal University.

\section{References}

M.M. Keruly, R.R. Khusnutdinov, "Non-predicative verb forms in different system languages”. XLinguae, Vol. 11, pp 352-358, 2018.

R.K. Ishtanova. Verbs of the Tatar language in the semantic aspect: dis. ... Cand filol. sciences. Kazan 2002.284 pages.

A.M. Aydarova. Verbs of behavior in the Russian, Tatar and English languages: Diss. ... Cand filol. sciences. Kazan 2016, 202 pages.

F.A. Ganiev. Modern Tatar literary language: suffixal and phonetic word formation. Kazan: Print House, 2005, 360 pages.

Tatar grammar. Kazan: Tatarsky kn. publishing house, 1993. Vol. I, 559 pages.

A.N. Eniki. Saylanma äsärlär. Kazan: (TARICH), 2002, 416 pages.
A.N. Enikeev. Stories and short stories. Translation from Tatar by A. Badyugina. Kazan, 1982. 256 pages.

LM. Akhmetzyanova, G.Kh. Gilazetdinova. "Lexico-semantic and linguo-stylistical analysis of A. Vvedensky's and D. Kharms' art texts", XLinguae, Vol. 11, pp. 455-470, 2018.

K. Shermaymayti, A.Sh. Yusupova, E.N. Denmukhametovan. "Loans of word in synonymy of the Tatar language", National academy of managerial staff of culture and arts herald, vol 2, pp. 270-273, 2018.

G.N. Khusnullina, R.M. Bolgarova, E.A. Islamova, M.S. Zholshayeva. "Comparisons of dishware names in Tatar and Russian languages", AD ALTA: Journal of Interdisciplinary Research, Vol 7, pp. 112-115, 2017.

Rezaei, M., \& Nemati, K. (2017). The Impact of Purchase Intent, Word of Mouth Advertising and Skill Domain of Seller on Quality of Customer Relationship to Sale Life and Savings Insurance Policies (Case Study: Dana Insurance Co., Bushehr Province). Dutch 
Journal of Finance and Management,

$1(2)$

43.

https://doi.org/10.29333/djfm/5819

Mnunguli, J. P., \& Kisangiri, M. (2018).

Evidence based Practices for Drug Abuse Information Management and Awareness Approaches. Journal of Information Systems Engineering \& Management, 3(4), 31.

Metsämuuronen, J. (2018). Common

Framework for Mathematics Discussions of Possibilities to Develop a Set of General Standards for Assessing Proficiency in Mathematics. International Electronic Journal of Mathematics Education, 13(2), 13-39. https://doi.org/10.12973/iejme/2693

Zhampeisov, K., Balykbayev, T., Kolumbayeva, N. K. S., \& Aitpayeva, A. (2018). National Component of the Training Content of the Teachers in Kazakhstan's school. Opción, 34(85-2), 653-677 